\title{
Marine-derived pipeline anticancer natural products: a review of their pharmacotherapeutic potential and molecular mechanisms
}

\author{
Mohamed Ali Seyed ${ }^{1 *}$ (i) and Siddiqua Ayesha ${ }^{2}$
}

\begin{abstract}
Background: Cancer is a complex and most widespread disease and its prevalence is increasing worldwide, more in countries that are witnessing urbanization and rapid industrialization changes. Although tremendous progress has been made, the interest in targeting cancer has grown rapidly every year. This review underscores the importance of preventive and therapeutic strategies.

Main text: Natural products (NPs) from various sources including plants have always played a crucial role in cancer treatment. In this growing list, numerous unique secondary metabolites from marine sources have added and gaining attention and became potential players in drug discovery and development for various biomedical applications. Many NPs found in nature that normally contain both pharmacological and biological activity employed in pharmaceutical industry predominantly in anticancer pharmaceuticals because of their enormous range of structure entities with unique functional groups that attract and inspire for the creation of several new drug leads through synthetic chemistry. Although terrestrial medicinal plants have been the focus for the development of NPs, however, in the last three decades, marine origins that include invertebrates, plants, algae, and bacteria have unearthed numerous novel pharmaceutical compounds, generally referred as marine NPs and are evolving continuously as discipline in the molecular targeted drug discovery with the inclusion of advanced screening tools which revolutionized and became the component of antitumor modern research.

Conclusions: This comprehensive review summarizes some important and interesting pipeline marine NPs such as Salinosporamide A, Dolastatin derivatives, Aplidine/plitidepsin (Aplidin ${ }^{\circledR}$ ) and Coibamide A, their anticancer properties and describes their mechanisms of action (MoA) with their efficacy and clinical potential as they have attracted interest for potential use in the treatment of various types of cancers.
\end{abstract}

Keywords: Marine NPs, Anticancer therapy, Dolastatin 10/15, Marizomib, Aplidine/plitidepsin, Coibamide A, Apoptosis

\section{Background}

Cancer is a most widespread complex disease and its prevalence is increasing worldwide $[1,2]$, more in countries that are witnessing urbanization and rapid industrialization changes [3-7]. It is a normal pathologic

\footnotetext{
*Correspondence: sdmdali.ali@gmail.com

1 Department of Biochemistry, Faculty of Science, University of Tabuk,

Tabuk 71491, Kingdom of Saudi Arabia

Full list of author information is available at the end of the article
}

condition in which dysfunctional mechanisms in cell cycle regulation and insufficient programmed cell death (PCD) [8-10]. Inhibition of PCD or apoptosis plays a prominent role in the origin and progression of cancers [11]. In recent years, technical advancements made an increased attention toward cancer progression both at cellular and molecular level [12-16], this increased attention on multiple human malignancies witnessed huge development which will fight the cancer in multiple 
fronts by adopting novel diagnosis and therapeutic options.

Cancer therapy played a key role in the control of tumor progression and help to cure and prolong the life of patients [17-20]. The most acceptable preventive and therapeutic approach is to circumvent the exposure to the causative agents of cancer, to enhance the host defence mechanism against cancer, to alter the living style, chemoprevention and treatment using natural products and their derivatives [21-23]. This highlights the necessity to explore more novel effective and less toxic chemotherapeutic natural drug components and their sustainable supply for cancer therapy [24].

\section{Natural products and their contributions to alleviate human diseases}

About $60 \%$ of the chemotherapeutic drugs that are in current use are either natural products (NPs) or small compounds, which are mostly NP based drug leads [2528]. However, the characterization of these NPs and their direct access is still pose a great challenge [29]. Though majority of the traditional and the most commonly available medicinal plants have proved to be an excellent source for the bioactive components and are promising as an antitumor agents. In this growing list, a vast diversity on chemical structure with potent biological activity from the marine environment also offers novel structural entities which demonstrates to be an excellent resource for the new and unique source of anticancer drugs [28, 30-33]. In addition to the chemical novelty related to those compounds they also possess novel and new mechanism of action [34, 35]. However, the intense toxic nature of certain marine bioactive compounds like maitotoxin, brevetoxin B prevents them from being used in therapeutic applications, whereas others such as palytoxin, okadaic acid and fluorescent proteins from marine organisms are used as an indispensable tools for drug development, mostly in clinical or under preclinical tests $[36,37]$.
Early investigations of National Cooperative Drug Discovery Program (NCDDP), an inspired program conducted by the National Cancer Institute (NCI) [38, 39] was not translated the jewel of marine entities into well-known drug leads or pharmaceutical components. This may be due to the inadequate connections between the academic researchers and the pharma industries. At present, subsequent to the collaborative interactions between the academics and the major pharmaceutical sectors have encouraged and paved way to the discovery of large number of marine NP materials being tested in modern assays [40].

\section{Main text}

Marine NPs and the drug leads possess a very distinct structural feature compared to their counterparts on earth [32, 33], which is either due to the alterations in the evolutionary origin or the environmental condition which are specific to the marine world [41]. When exposed to extreme conditions those marine organisms that live in complex habitats are capable of producing a vast variety of secondary metabolites which is not possible by other organisms [42]. Moreover, the production of very potent marine-derived molecules like polyunsaturated fatty acids (PUFAs), sterols, proteins, polysaccharides, antioxidants and pigments have led to inhibit various types of human cancers both in vitro and in vivo murine and human trials. This led to tremendous attention toward other marine sources including cyanobacteria [43], which yielded compounds like curacin A and dolastatin 10. As a result, Eribulin (a synthetic derivative based on the structure of halichondrin B), and monomethyl auristatin E (MMAE or vedotin), pipeline warheads of dolastatin 10 derivatives have been approved by FDA for human applications [44]. Some of the clinically approved marine drugs for various human cancers [45] are listed in Table 1.

There are about 592 marine natural products have exhibited very strong antitumor and cytotoxic activities.

Table 1 List out some of U.S FDA approved clinical drugs for various human diseases obtained from marine sources

\begin{tabular}{|c|c|c|c|c|}
\hline Compound name & Marine organism & Molecular target & Indication & Approval date \\
\hline Trabectedin & Tunicate & Tunicate DNA (minor groove) & Soft tissue sarcoma and ovarian cancer & October 23, 2015 \\
\hline Brentuximab vedotin & Mollusk/cyanobacteria & CD30, microtubules & $\begin{array}{l}\text { Anaplastic large T-cell systemic malig- } \\
\text { nant lymphoma, Hodgkin's disease }\end{array}$ & August 19, 2011 \\
\hline Eribulin mesylate & Sponge & Microtubules & Metastatic breast cancer 0 & November 15, 2010 \\
\hline Omega-3-acid ethyl esters & Fish & Triglyceride-producing enzymes & Hypertriglyceridemia & November 10, 2004 \\
\hline Ziconotide & Cone snail & DNA polymerase & Severe and chronic pain & December 28, 2004 \\
\hline Vidarabine & Sponge & Viral DNA polymerase & Herpes simplex virus infection & $\begin{array}{l}1976 \text { current status: } \\
\text { Discontinued }\end{array}$ \\
\hline Cytarabine & Sponge & DNA polymerase & Leukemia & 1969 \\
\hline
\end{tabular}


Besides, nearly 666 additional chemicals have demonstrated various pharmacological actions, which include anticoagulant, antimicrobial, antiplatelet with varied mechanisms of actions on multiple systems like cardiovascular, nervous, endocrine and immune were also included in the marine pharmaceutical pipeline worldwide during the period 1998-2008 [37]. Inspite of various successes and setbacks, worldwide focus toward marine compounds as preclinical cum pharmaceutical pipeline drugs still remains very active (Table 2). In this regard, though there are many compounds that have entered the clinical trials for cancer; however, only eight marine drugs have been recognized and approved by FDA and European Agency for the Evaluation of Medicinal Products (EMEA), they are Cephalosporin C, Cytarabine (Ara-C), Yondelis ${ }^{\circledR}$ (ET743), Vidrabine (Ara-A), Ziconotide (Prialt), omega-3-acid ethyl esters (Lovaza), ET-743 (Yondelis), E7389 (Halaven), Brentuximab vendotin (SGN-35) [36, 46].

An undeniable fact is that the constant supply, isolation, and characterization of NPs is a major challenge for the marine as well as other sources as they are one of the major inevitable components in antitumor drug discovery research. However, in recent years, modern approaches are emerging to overcome these obstacles. In the competitive industrial pharmaceutical grounds, the most widely employed methods for antitumor drug discovery is high-throughput in vitro assay, which permits to examine interactions between small molecules and their target proteins. [14, 47-50]. However, these sophisticated high-throughput screening systems typically requires collaborative efforts, enabled by a mutual research between marine combinatorial chemists and molecular and cell biologists [51]. Developments and events in various technologies such as sampling strategies, total chemical synthesis, fermentation, nanoscale nuclear magnetic resonance (NMR) for structure determination, recent biotechnology advancements are imminent for achieving goals to see marine NPs as potential pipeline drug leads. A high degree of novelty and modernization in the area of marine compounds has led to a new arena in the regeneration of new pharmaceuticals in the coming years [29].

Different mechanisms have been proposed for the drugs discovered from marine organisms including cell death like apoptosis, effect on the tubulin-microtubule equilibrium or induction of angiogenesis inhibition. Though these findings has augmented our understanding of these new marine drug leads and their properties and seen as a new option for acquiring enormous potential drug-lead molecules on pharmaceutical discovery [50, 52]. Despite the huge effort made progress of anticancer compounds from marine resources, but in reality this domain of research is stand at the infant stage because only few marine compounds have been identified and isolated till date when compared with other natural sources.

Regardless of the above fact, it is evident that the biological properties of marine NPs potentially interfere with the genesis and progression of many human diseases including cancer [52, 53]. Therefore, to facilitate the importance of jewels of these unique marine world this review summarizes the existing scientific knowledge and highlights few selected potential pipeline marine NPs (such as Salinosporamide A, Dolastatin 10/15 derivative, Aplidine/plitidepsin (Aplidin ${ }^{\circledR}$ ) and Coibamide (Figs. 1, 2, $3,4,5)$, which are currently under clinical evaluation as a pipeline anticancer agents to fight against cancer.

\section{Anticancer potentials of pipeline marine NPs Salinosporamide $A$ in cancer treatment}

In the academic drug discovery arena, marine microbes are now emerging as a new sustainable source for novel drug chemical substances [40, 41, 53]. Actinomycetes marine bacteria is one such rich source for novel compounds, which belongs to genus Salinispora [54-56]. One of the most promising drug lead is salinosporamide A, a natural product, which is highly potent proteasome inhibitor discovered by [57]. It is a chlorinated clinically promising anticancer agent, isolated from marine bacterium (Actinomyces) Salinispora tropica and Salinispora arenicola [54] and is initially assessed in multiple myeloma (MM) xenograft models [58] but later in a series of clinical trials (phase 1) as a single agent against other types of solid tumors and lymphomas [57, 59-62] and under the name NPI-0052/Marizomib (Fig. 1).

Subsequent studies further revealed the mechanism of action of this compound as a proteasome inhibitor [63, 64]. Since proteasome inhibitors play a crucial role in controlling the level of proteins in the control of cancer [65]. Till date, the only clinically approved proteasome inhibitor is bortezomib [66] and others are under clinical trials. Currently, Salinosporamide A is in clinical trials for MM treatment either as a single agent [67-70] or with an aid of the existing treatments [71]. Salinosporamide A covalently binds to the threonine residues in the proteasome active site and inhibits the proteasome $20 \mathrm{~s}$ activity. The proteasome inhibition has been applied as an effective strategy in the treatment of MM and some lymphomas [64, 70], as they block nuclear factor-kappa $\mathrm{B}(\mathrm{NF}-\mathrm{\kappa} \mathrm{B})$ activity by interfering with the growth and survival signaling [72-78]. As this drug has moved ahead to phase-I clinical evaluation, salinosporamide $A$ is at present being manufactured by saline fermentation process [79], to increase the yields and lower the cost of production. 


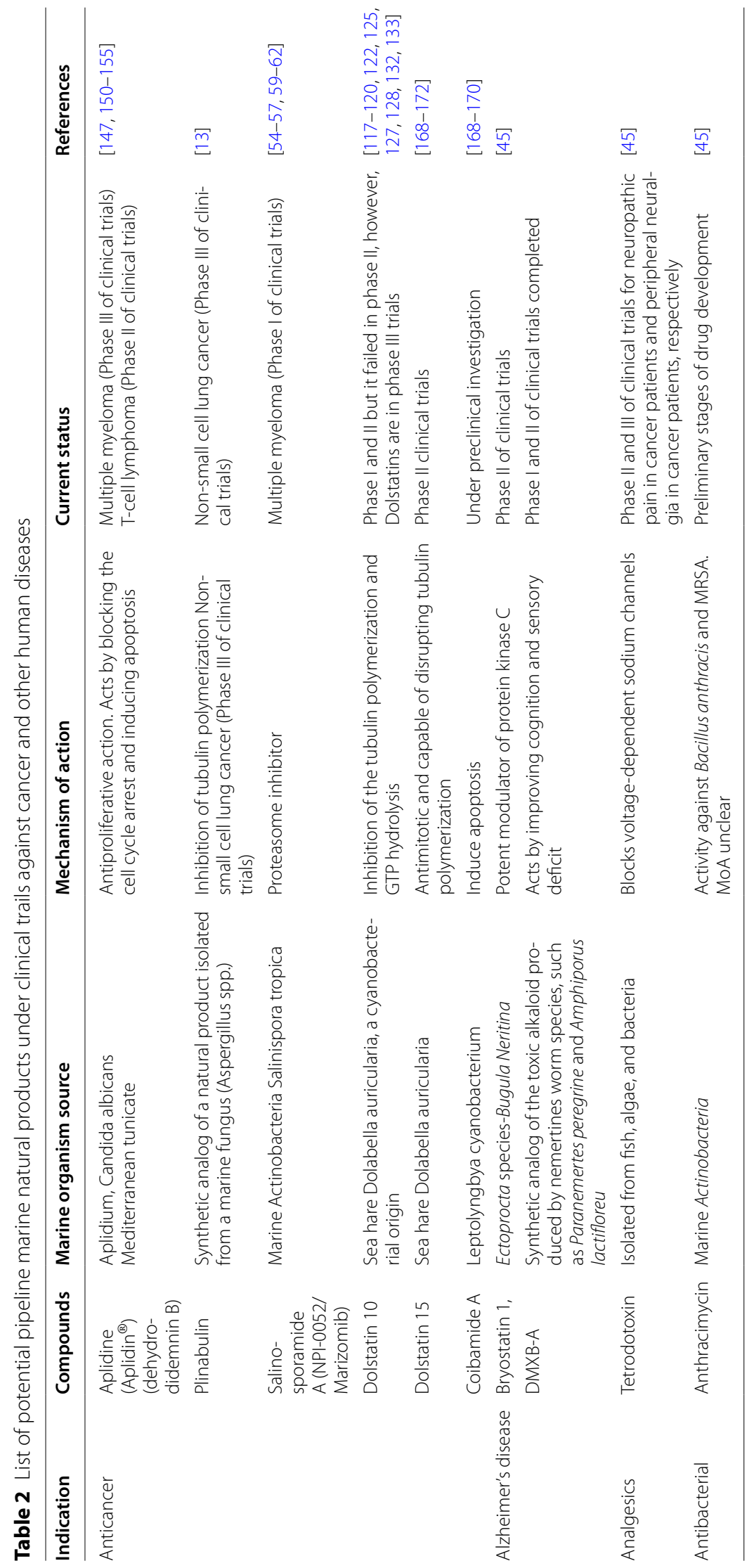




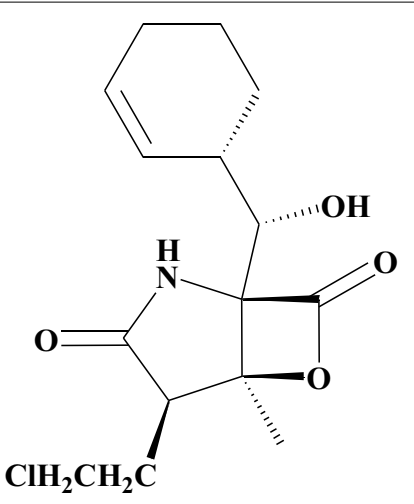

Marizomib (NPI-0052)

Fig. 1 Marizomib (NPI-0052)

\section{Marizomib $^{\circledR}(\mathrm{NPI}-0052)$}

Marizomib $^{\circledR}$ (NPI-0052), the second-generation proteasome inhibitor of Salinosporamide A is a more promising pipeline drug and had shown a best clinical activity in bortezomib-resistant cancers. Besides the above, it was effectively developed and found to hold on to various pharmacological properties and broader anticancer activity. Marizomib binds to the active site of the proteasome $[69,77,80]$ and has exposed its clinical activity either as a single drug lead or in combination with other antitumor compounds such as dexamethasone. Marizomib shares analogous properties but often is known to exhibit higher efficacy than its parental drug. It also exhibited higher activities in multiple non-clinical tumor models treatment of patients with hematologic and solid tumors [54, 60-62]. MM is a fatal disease with the excessive proliferation of plasma cells. Due to the development of these kinds of novel agents, the survival rate of patients suffering from MM has been improved significantly [81]. Over and above, it also portrayed synergistic effects in the cancer models when combined with immunomodulatory agent lenalidomide, and a range of histone deacetylase inhibitors [82].

\section{Molecular mechanism of Marizomib}

Proteasome is an intracellular enzyme complex that is capable of regulating the protein levels in the cell by degrading the ubiquitin-tagged proteins. Proteasome is categorized into its subcomponents based on their Svedbergs sedimentation coefficient. The $20 \mathrm{~S}$ proteasome is a collection of four stacked disks that forms a hollow complex, each of which includes 7 subunits that are called as $\alpha 7-\beta 7-\beta 7-\alpha 7$ structure [83] and three kinds of $\beta$-subunits: post-glutamyl peptidyl hydrolytic-like
(PGPH, $\beta 1)$, trypsin-like (T-L, $\beta 2)$ and chymotrypsinlike (CT-L, $\beta 5)$ activity area that are capable of performing unique enzyme activities respectively [83, 84]. These $\beta$-subunits are distinguished from the other proteases by the presence of an amino terminal (N-terminal) threonine residue in all the three catalytic sites that provide as a nucleophile for proteolysis $[74,85]$.

Multiple evidences demonstrate that a dysregulation of critical regulatory proteins that relates various signaling pathways lead to cell cycle arrest as apoptosis is been created by the inhibition of proteasome $[86,87]$ and also exhibited numerous anticancer properties against numerous types of cancer using various xenograft models like prostate [88] pancreatic [89]) lymphoma [90], head and neck [91] melanoma [92], lung [93], breast [94], and leukemia [95]. Thus cancer treatments can accomplished via programmed cell death caused by proteasome inhibitors [96-98]. The nuclear factor of $\kappa \mathrm{B}(\mathrm{NF}-\mathrm{\kappa B})[88,99]$, tumor suppressor p53 [100], cyclins [101, 102] etc. are some of the proteasome substrates. While in most cases, the cell death resulting due to proteasome inhibition which requires the activation of caspases [103] and has been linked to increased levels of oxidative radicals [88, 93, 104]. Commonly, both Bortezomib and Marizomib are well to increase caspases $3,4,8$ and 9 activity [105, 106], yet, NPI-0052 exhibits its potency mostly through caspase-8-dependent pathway [107].

Besides, the evaluation of antitumor efficacy of both bortezomib and Marizomib was carried out by assessing the efficacy of the agent using various preclinical studies [108-113]. In view of the fact that, bortezomib largely interacts with the CT-L and T-L active sites of proteasome and NPI-0052 potently inhibits all the three active sites, it is proposed that using both bortezomib with NPI0052 would benefit more and seen as a viable approach for wide range of manifestations. In line with this, previous study has established that that the combination strategy of these two agents evident with synergistic antiMM activity in both in vitro and in vivo models [114]. To support this findings, similar results were obtained with the combination of Marizomib and lenalidomide combination $[68,79,104,115]$. However, the molecular mechanisms of the synergetic actions, which include the inhibition of proteasome, activation of caspases-8, 9 and 3, and PARP cleavage [79]. Therefore, Marizomib is viewed for their unique exceptional profiles after three verified clinical trials [116].

\section{Dolastatins and their analogs in cancer treatment}

In addition to the above, in recent years, microtubules are the prime target and serve as the components of anticancer therapy by using taxanes and vinca alkaloids which are acting as an antimitotic agent that target intracellular 


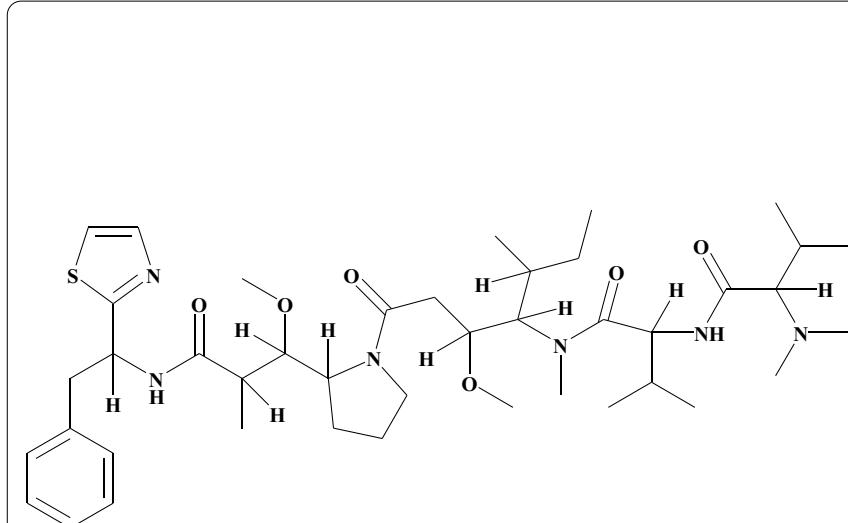

A: Dolastatin 10
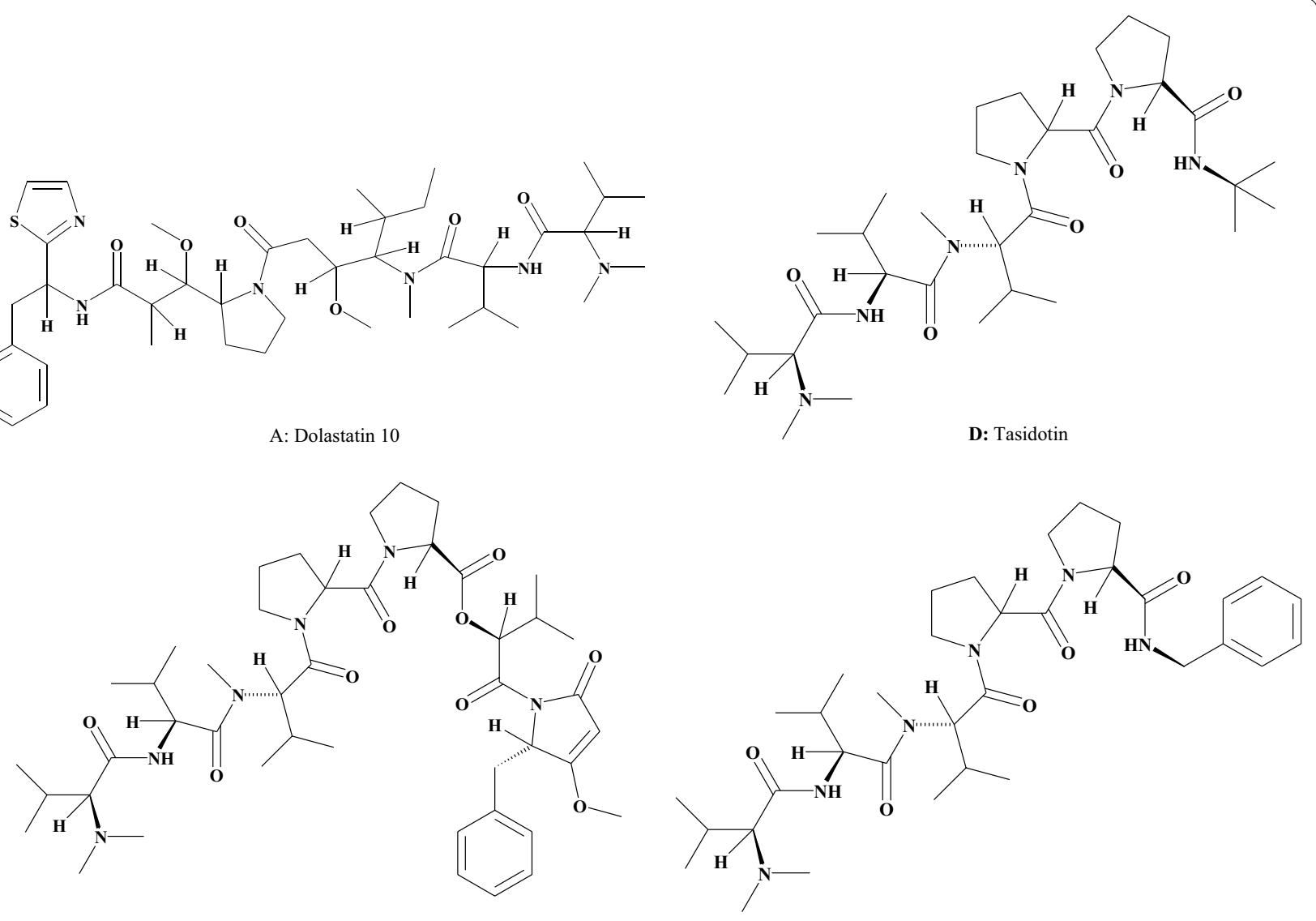

B: Dolastatin 15

E: Cemadotin

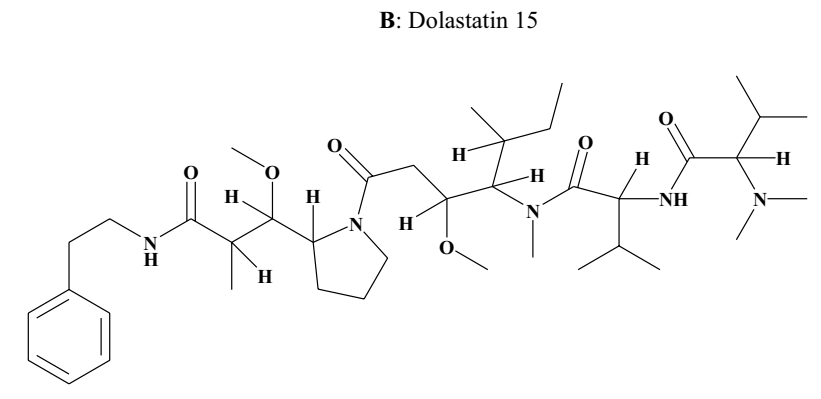

C: TZT-1027 (auristatin PE)

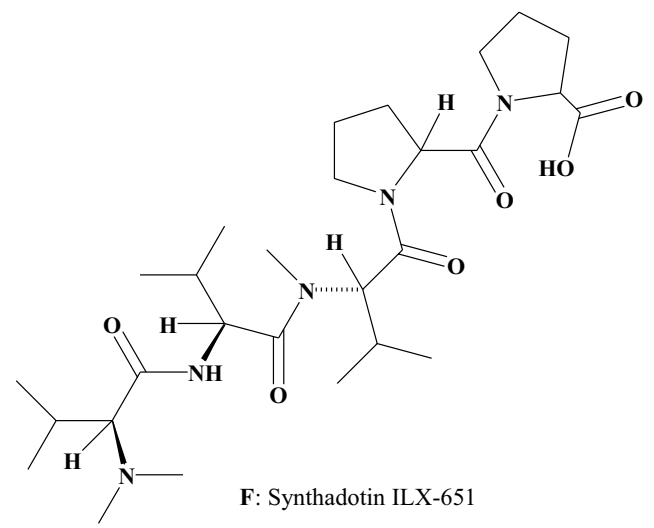

Fig. 2 a. Chemical structure of the marine Sea hare Dolabella auricularia, Dolastatin 10. b. Chemical structure of the marine Sea hare Dolabella auricularia, Dolastatin 15. c Chemical structure of an analog of Dolastatin 10, TZT-1027 (auristatin PE). d Chemical structure of an analog of Dolastatin 10, Tasidotin. e Chemical structure of an stabilized analog of dolastatin 15 Cemadotin. $\mathbf{f}$ Chemical structure of an dolastatin 15 synthetic analog Synthadotin ILX-651

organelle tubulin $[117,118]$. Even though these antimitotic drugs are highly successful in the treatment of a many types of cancers, the major clinical problem lies are both acquired and intrinsic resistance to these components. Avast array of potential new generation antimitotic drug leads are now under clinical trials. In line with this, Dolastatins and their analogs are emerging as anticancer drugs because they function as a vascular disrupting agent (VDA) [119, 120].

Dolastatin 10 (Fig. 2a), a linear pentapeptide has numerous unique amino acid subunits, originally isolated from the sea hare Dolabella auricularia 


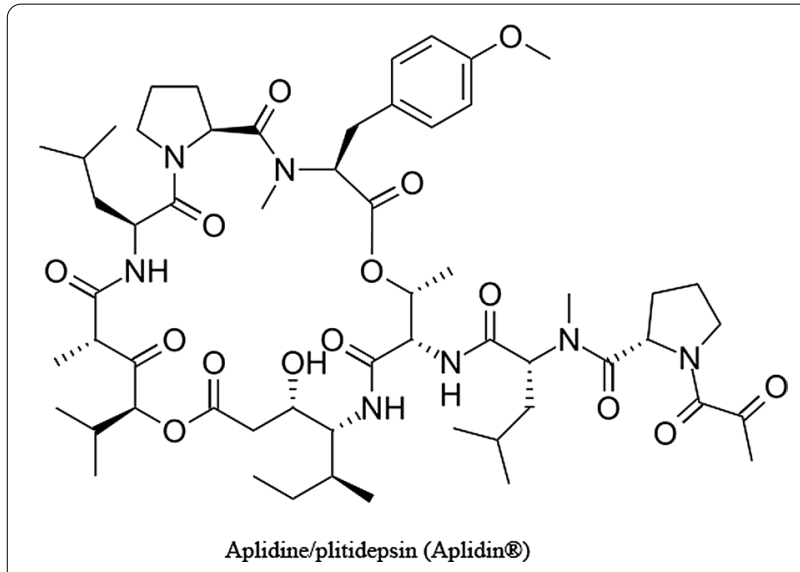

Fig. 3 Chemical structure of an Mediterranean marine tunicate Aplidium albicans derived Aplidine/plitidepsin (Aplidin ${ }^{\circledR}$ )

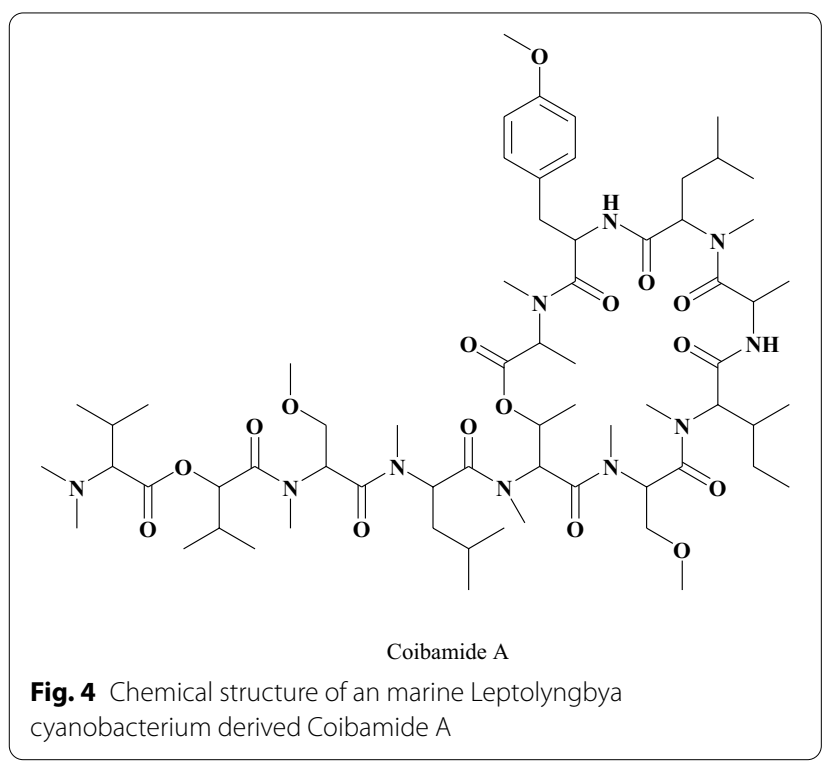

[121-125], commonly originate from cyanobacteria, which belongs to the genera Symploca and Lyngbya upon they feed [126-129]. Elucidating the structure of Dolastatin has taken nearly 15 years for completion due to very little information on this active principle $[130,131]$ Preliminary studies have indicated that [129], the binding of the Vinca alkaloids to tubulin and the microtubule assembly is strongly inhibited by Dolastatin 10 [130]. A tripeptide portion of Dolastatin 10 which do not significantly inhibit the binding of vincristine or the exchange of nucleotides however efficiently inhibits the tubulin polymerization and GTP hydrolysis [131]. Besides, another sea hare D. Auricularia and cyanobacterial origin is antimitotic Dolastatin 15 (Fig. 2b), results are again strongly implicating that this metabolite is potent pipeline agent as marine cyanobacteria once again proven as a source for the isolation of numerous dolastatin 15-related peptides [122, $125,132,133]$.

\section{Mechanism of action of Dolastatins}

Dolastatin 10 has demonstrated its potency against various human cancers such as lymphomas, leukemias and solid tumors [129, 134, 135]. At very low concentrations, dolastatin 10 cause microtubules depolymerization and produced mulitpolar spindles leading to cell apoptosis [130, 131, 136]. Subsequent research investigation supported that dolastatin 10 binds to the rhizoxin/maytansine binding site [137], which is next to Vinca alkaloid site as well as exchangeable to the guanosine triphosphate site on tubulin, causing cell cycle arrest in metaphase [138]. Currently Dolastatin 10 derivatives are in the clinical trials of both phase I and phase II [1254] as a pipeline compound for treatment of several solid tumors [127, 128]. However, it failed to show any significant clinical activity in Phase II clinical trials due to certain issues such as the productivity based on the multistage chemical synthesis steps and the lack of water solubility, analouges such as TZT-1027 (auristatin PE) (Fig. 2c) [139-141]. Despite the above, these analogs are at phase III clinical trials [142]. This synthetic analog of dolastatin 10, exhibited an enhanced activity in pilot studies using various animal models and showed its synergistic antitumor property in combination with Cisplatin [136] in the human (HCT-116) and murine colon (26 adenocarcinoma) cancer model [143]. It is interesting to note that the outcome of TZT-1027 on tumor blood vessels and HUVEC were considerable when compared to Vincristine. Moreover, TZT-1027 was effective in MX-1 breast carcinoma and LX-1 lung carcinoma [144]-the two human xenograph models.

In line with this, Tasidotin (Fig. 2d) is an analog of Dolastatin with tubulin-interactive activity that inhibits tubulin polymerization very weakly, but suppresses the dynamic instability of microtubules strongly. [129]. At present it is at the Phase III trials [145] and had successfully completed the Phase I trials $[134,135]$. Results suggested that both TZT-1027 and Tasidotin with a putative protein kinase-dependent mechanism targeted a quick attack of the vascular system of the advanced cancers and thus blocked the blood flow in the tumor. Henceforth, TZT-1027 has made a tremendous progress and proven as powerful agent for tumor therapy.

Cematodin (LU-103793; Fig. 2e), is a water-soluble and a stabilized analog of dolastatin 15 [146] was synthesized in the year 1995, with a original dolapyrrolidone replaced by benzylamine moiety terminal. It is capable of disrupting tubulin polymerization and inducing 


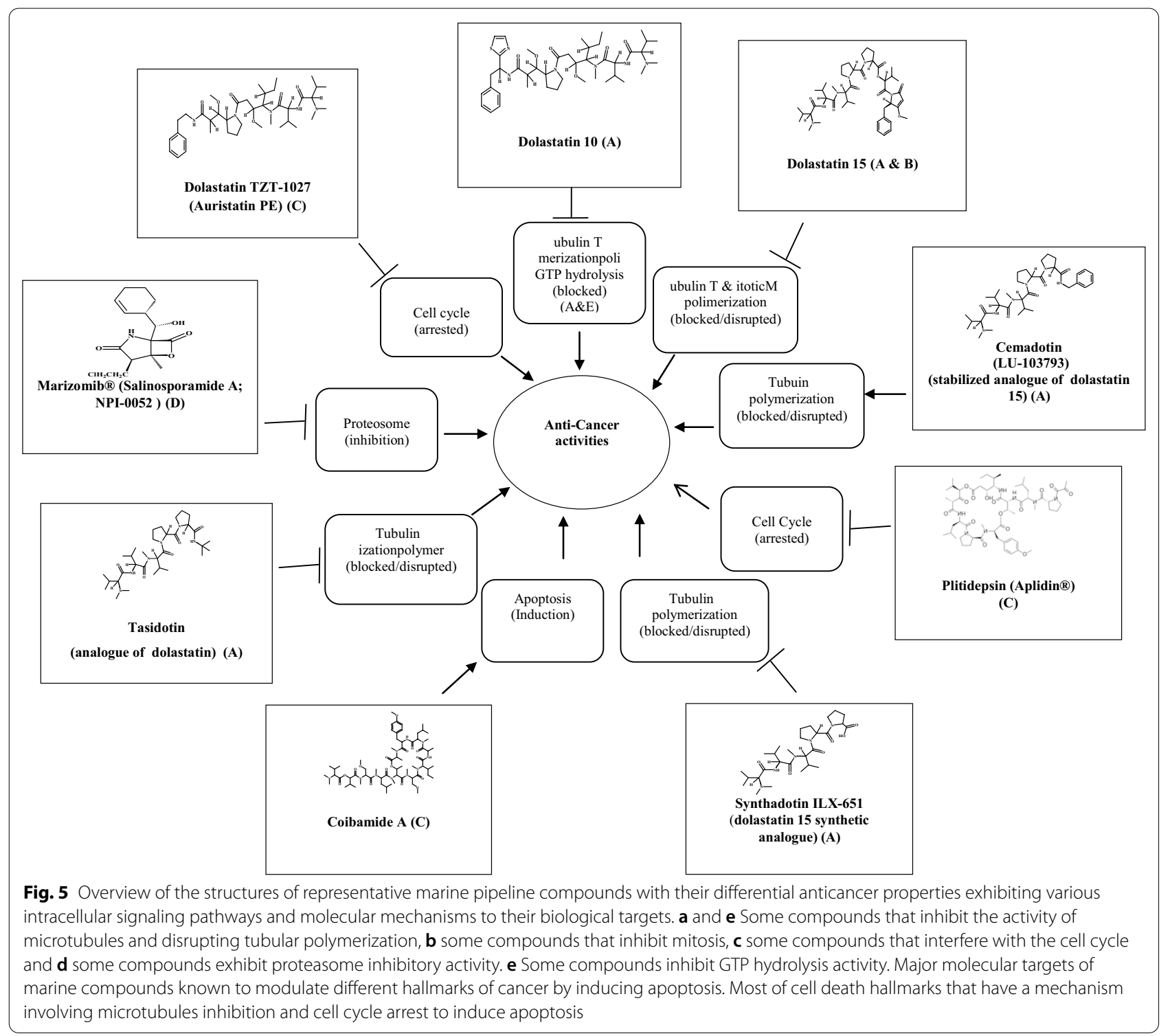

depolymerization of preassembled microtubules through the retention of high cytotoxicity like parent compound [147]. In addition, Synthadotin (Fig. 2f), ILX-651 an orally active a 3rd generation dolastatin 15 synthetic analog possessing a terminal tert-butyl moiety when compared to the original dolapyrrolidone is under phase II clinical trials using patients with locally advanced or metastatic non-small cell lung tumors and patients with hormone-refractory prostate cancer previously treated with Docetaxel [148]. A clinical outcome of this phase II trial, in which patients with inoperable advanced or metastatic melanoma treated with ILX-651 for consecutive 5 days on a 3 week period indicated that it was a "safe, well-tolerated treatment for locally advanced and metastatic melanoma patients" [149].

\section{Plitidepsin (Aplidine) in Cancer treatment}

Plitidepsin (Fig. 3), also known as dehydrodidemnin $\mathrm{B}$, (trade name Aplidin) is a cyclodepsipeptide isolated from Aplidium albicans, which is a Mediterranean tunicate $[147,150]$. Plitidepsin is considered as a new generation didemnin that portrays higher anticancer activity and better therapeutic indexes than didemnin B at nontoxic concentrations and now being developed by total synthesis. Plitidepsin is a well-tolerated drug which has exhibited its strong antitumor property both in in vitro and mouse model using numerous human cancer cell lines. To support this, both Phase I and Phase II clinical trials also showed hopeful results of anticancer activity [151-155] and currently undergoing phase III trial as a therapeutic agent for relapsed/refractory MM patients. 
Previous studies has demonstrated that plitidepsin is capable of inducing cell cycle arrest either by cell-specific or dose-dependent manner [152, 156, 157]. Besides, a sustained activation of JNK and p38 MAPK is made possible by the combined actions like early oxidative stress induction, activation of Rac1 GTPase and inhibition of protein phosphatases activity [158].

\section{Mechanism of action of plitidepsin}

The mechanism of action of plitidepsin on tumor cells is well described [152]. In brief, after an interaction with the high affinity binding site in the cell membrane, plitidepsin leads to the rapid activation of Rac1 and the persistent phosphorylation and activation of JNK and p38/MAPK that eventually induce apoptosis [152, 159, 160]. Activation of JNK and p38 MAPK results in the downstream signaling events like cytochrome c release, activation of caspases- 9 and -3 and PARP cleavage, thus signifying the mediation/significance of the mitochondrial apoptotic pathway in this process. In addition, several pathways have also involved in Alphidine's mechanism of action which includes cell cycle arrest and protein synthesis inhibition $[161,162]$ in leukemic cells with the involvement of translocation of Fas/CD95 in lipid rafts [163-166]. Moreover, the induction of oxidative stress by Plitidepsin incites a stress on the endoplasmic reticulum (ER) also associated to cell death [152]. In this regard, Plitidepsin activates important molecular machinery of the classical ER stress-induced unfolded protein response (UPR) as well as the phosphorylation of eIF2 $\alpha$ and JNK. Due to its fast degradation by the ubiquitin/proteasome machinery Plitidepsin also induces the decrease of CHOP protein levels. [167].

\section{Coibamide $A$ in cancer treatment}

Coibamide A (Fig. 4), is a marine product from Leptolyngbya cyanobacterium, mostly available in Panama [168-170] and identified as a novel and an effective anatiproliferative depsipeptide anticancer drug. The structure represents a methyl-stabilized cyclic depsipeptide with a lariat side chain, and the activity of the structure portrays that there is a direct effect on Coibamide A, if there is a loss in the N-methylation which results in the disjoining of the cyclic and the side chain structures of the molecule or just a drastic linearization of the molecule [171]. Thus it induces the apoptotic activity by activting caspase- 3 and caspase- 7 and non-apoptotic cell death activity in the apoptosis-resistant human cancer cells which include U87-MG, NCI-SF-295 glioblastoma (GBM) respectively and works in concentration-dependent and cell cycle active $[168,171]$ manner. The cell death also observed in the wild-type and autophagy-deficient (ATG5-null) and knockout (KO) mouse embryonic fibroblasts (MEFs) indicates its novel mechanism of action [171]. A cytostatic effect that arrested the G1 phase cell cycle with minor change in G2/M and loss of S phase was portrayed in the flow cytometric analysis. In addition, it also inhibits the glioma cell motility especially invasion and not migration [169]. Besides the above, the mutations that occur throughout the GBM, results in the activation and enhancement of receptor tyrosine kinases EGF, PDGF as well as attenuation of the tumor suppressor genes such as p53 and PTEN (phosphatase and tens in homolog [172]. Thus, an increase in the cell signaling is observed due to MAPK (Mitogen Activated Protein Kinase) and PI3K (Phosphatidylinositol 3- kinase) pathways leading to the promotion of the cell survival and henceforth GBM attains resistance to apoptosis. A test for the anticancer activity using 60 cancer cell lines demonstrated that Coibamide A portrayed a high potential of activity in a range that falls between 2.8 and $7.6 \mathrm{nM}$ but mostly selective to 4 different cell lines such as breast (MDAMB-23, melanoma (LOX IMVI), human leukemia (HL-60) and glioblastoma (SNB-75), however exhibited significant histological selectivity for breast, CNS, colon and ovarian cancer cells [168].

Moreover, the effect of this peptide on mTOR protein was studied and concluded that Coibamide A possess mTOR independent cellular response and induces rapid and regular and also sustained autophagic response [171]. Besides, it was potrayed that Coibamide A induced cell death could be accomplished through apoptotic or non-apoptotic pathways not necessarily by autophagy alone. To support the above, evidences show that many cytotoxic marine anticancer NPs trigger apoptosis by targeting multiple cellular proteins by involving both intracellular and extracellular pathways [173]. Those marine NPs that are capable of inducing apoptosis were primarily recognized as cytotoxic agents, however their apoptotic activity was discovered later by various secondary pharmacological evaluations. In fact, Coibamide A has also displayed potent caspases-dependent apoptotic activity in different cancer cells.

\section{Conclusions}

In summary, the past two decades have witnessed a resurgence and revolution on new drug discovery from marine sources. In this review, we have discussed the role of few important pipeline marine peptides, their mode of action (Fig. 5) and the hitches related to the transfer of marine NPs into various phases of clinical trials. The peptide molecules reviewed are acquired from different marine sources and each of those portrays a different but unique mechanism of action and exhibited their anticancer activities. The peptides from marine sources share a diversified style and class and the presence of more number of cyclic peptides 
or depsipeptide is an important property of the marine organisms. Though several marine peptides display anticancer activities on multiple tumor targets. The available results clearly indicate that these potential pipeline drugs such as Salinosporamide A, Marizomib, Plitidepsin, Coibamide A appears to be very potent and promising pipeline drugs not only biomedical science but also serve as cancer therapeutics. Hence, the diversity of marine peptides both in terms of structure and mode of action provide a valuable source for the drug design and serve as novel new pharmaceuticals for a wide variety of human cancers.

\begin{abstract}
Abbreviations
PCD: Programmed cell death; NPs: Natural products; NCDDP: National Cooperative Drug Discovery Program; PUFAs: Polyunsaturated fatty acids; MME: Monomethyl auristatin E; FDA: Food and Drug Administration; EMEA: European Agency for the Evaluation of Medicinal Products; NMR: Nuclear magnetic resonance; MM: Multiple myeloma; NF-KB: Nuclear factor-kappa B; PGPH $\beta 1$ : Post-glutamyl peptidyl hydrolytic-like; T-L, $\beta 2$ : Trypsin-like; CT-L $\beta 5$ : Chymotrypsin-like; PARP: Polyadenyl ribose polymerase; VDA: Vascular disrupting agent; GTP: Guanosine-5'-triphosphate; JNK: C-Jun N-terminal kinases; MAPK: Mitogen-activated protein kinase; Rac1: Rac Family Small GTPase 1; ER Endoplasmic reticulum; elF2a: Eukaryotic initiation factor-2a; CHOP: CCAAT/ enhancer binding proteins; GBM: Glioblastoma; PTEN: Phosphatase and tens in homolog; EGF: Epidermal growth factor; PDGF: Platelet-derived growth factor; PI3K: Phosphatidylinositol 3-kinase; mTOR: Mammalian target of rapamycin.
\end{abstract}

\section{Acknowledgements}

Not applicable.

\section{Authors' contributions}

MAS inscribed the major part of the manuscript contributed to the guiding and configuring of the manuscript. SA contributed to the writing of the manuscript in various segments and in preparing figures. All authors have read and approved the manuscript.

\section{Funding}

Not applicable (No funding support available for this review).

\section{Availability of data and material}

Not applicable.

\section{Declarations}

Ethics approval and consent to participate

Not applicable.

\section{Consent for publication}

Not applicable.

\section{Competing interests}

No competing interest to declare.

\section{Author details}

'Department of Biochemistry, Faculty of Science, University of Tabuk, Tabuk 71491, Kingdom of Saudi Arabia. ${ }^{2}$ School of Public Health, SRM University, Kattankulathur, Chennai, Tamil Nadu, India.

Received: 23 July 2021 Accepted: 29 September 2021

Published online: 15 October 2021
References

1. Bray F, Ferlay J, Soerjomataram I, Siegel RL, Torre LA, Jemal A (2018) Global cancer statistics 2018: GLOBOCAN estimates of incidence and mortality worldwide for 36 cancers in 185 countries. CA Cancer J Clin 68(6):394-424. https://doi.org/10.3322/caac.21492

2. World Health Organization (WHO) (2020) Global Health Estimates 2020: Deaths by Cause, Age, Sex, by Country and by Region, 2000-2019. WHO; 2020. https://www.who.int/data/gho/data/themes/mortalityand-global-health-estimates/ghe-leading-causes-of-death. Accessed 11 Dec 2020

3. World Cancer Report 2014 (2014) World Health Organization (WHO). Chapter 1.1. ISBN 9283204298

4. IARC (2011) Cancer Incidence and Mortality Worlwide; International Agency for Research on Cancer: Lyon, France

5. WHO, Global Status Report on Noncommunicable Diseases (2010) WT 500; WHO: Geneva, Switzerland

6. Ferlay J, Soerjomataram I, Dikshit R, Eser S, Mathers C, Rebelo M, Parkin DM, Forman D, Bray F (2015) Cancer incidence and mortality worldwide: sources, methods and major patterns in GLOBOCAN 2012. Int J Cancer 136(5):E359-E386. https://doi.org/10.1002/ijc.29210

7. Anwar MA, Kheir WA, Eid S, Fares J, Liu X, Eid AH, Eid AA (2014) Colorectal and Prostate Cancer Risk in Diabetes: Metformin, an Actor behind the Scene. J Cancer 5(9):736-744

8. Saikumar P, Dong Z, Mikhailov V, Denton M, Weinberg JM, Venkatachalam MA (1999) Apoptosis: Definition, mechanisms, and relevance to disease. Am J Med 107(5):489-506

9. Wyllie AH, Bellamy CO, Bubb VJ, Clarke AR, Corbet S, Curtis L, Harrison DJ, Hooper ML, Toft N, Webb S, Bird CC (1999) Apoptosis and carcinogenesis. Br J Cancer 80(Suppl 1):34-37

10. Reed JC (1999) Dysregulation of apoptosis in cancer. J Clin Oncol 17(9):2941-2953

11. Reed JC (2002) Apoptosis-based therapies. Nat Rev Drug Discov 1(2):111-121

12. Weinstein JN, Buolamwini JK (2000) Molecular targets in cancer drug discovery: cell-based profiling. Curr Pharm Des 6(4):473-483

13. Hertzberg RP, Pope AJ (2000) High-throughput screening: new technology for the 21st century. Curr Opin Chem Biol 4(4):445-451

14. Sikora K (2001) Cancer drug development in the post-genomic age. Curr Sci 81(5):549-554

15. Sung H, Ferlay J, Siegel RL, Laversanne M, Soerjomataram I, Jemal A (2021) Bray F (2021) Global cancer statistics 2020: GLOBOCAN estimates of incidence and mortality worldwide for 36 cancers in 185 countries. CA Cancer J Clin 71:209-249. https://doi.org/10.3322/caac.21660

16. Bray F, Laversanne M, Weiderpass E, Soerjomataram I (2021) The everincreasing importance of cancer as a leading cause of premature death worldwide. Cancer. https://doi.org/10.1002/cncr.33587

17. Rajesh E, Sankari LS, Malathi L, Krupaa JR (2015) Naturally occurring products in cancer therapy. J Pharm Bioallied Sci 7(Suppl 1):S181-183

18. Ovadje P, Roma A, Steckle M, Nicoletti L, Arnason JT, Pandey S (2015) Advances in the research and development of natural health products as main stream cancer therapeutics. Evid Based Complement Alternat Med 2015:751348

19. Hail N Jr, Cortes M, Drake EN, Spallholz JE (2008) Cancer chemoprevention: a radical perspective. Free Radic Biol Med 45(2):97-110

20. Editorial Report (2021) Advancing cancer therapy. Nat Cancer 2:245-246. https://doi.org/10.1038/s43018-021-00192-x

21. Hong WK, Sporn MB (1997) Recent advances in chemoprevention of cancer. Science 278(5340):1073-1077

22. Sun SY, Hail N Jr, Lotan R (2004) Apoptosis as a novel target for cancer chemoprevention. J Natl Cancer Inst 96(9):662-672

23. Sporn MB, Liby KT (2005) Cancer chemoprevention: scientific promise, clinical uncertainty. Nat Clin Pract Oncol 2(10):518-525

24. Seyed MA, Siddiqua, (2020) A review on the therapeutic potential of nature derived cholrin photosensitizer and its synthetic counterparts for photodynamic therapy in the control of neoplastic diseases. Int J PharmaO2 2(5):0315-0327

25. Cragg GM, Newman DJ, Snader KM (1997) Natural products in drug discovery and development. J Nat Prod 60(1):52-60

26. Cragg GM, Newman DJ (1999) Discovery and development of antineoplastic agents from natural sources. Cancer Invest 17(2):153-163 
27. Cragg GM, Newman DJ (2013) Natural products: a continuing source of novel drug leads. Biochim Biophys Acta 1830:3670-3695

28. Harvey AL (2008) Natural products in drug discovery. Drug Discov Today 13(19-20):894-901

29. Montaser R, Luesch H (2011) Marine natural products: a new wave of drugs? Future Med Chem 3(12):1475-1489

30. Villa FA, Gerwick L (2010) Marine natural product drug discovery: leads for treatment of inflammation, cancer, infections, and neurological disorders. Immunopharmacol Immunotoxicol 32(2):228-237

31. Liu Y (2012) Renaissance of marine natural product drug discovery and development. J Marine Sci Res Development 2:e106

32. Hanif N, Murni A, Tanaka C, Tanaka J (2019) Marine natural products from Indonesian waters. Mar Drugs 17(6):364. https://doi.org/10.3390/ md17060364

33. Carroll AR, Copp BR, Davis RA, Keyzers RA, Prinsep MR (2021) Marine natural products. Nat Prod Rep 38:362-413. https://doi.org/10.1039/ DONP00089B

34. Blunt JW, Copp BR, Keyzers RA, Munro MH, Prinsep MR (2012) Marine naturalproducts. Nat Prod Rep 29(2):144-222

35. Jiménez C (2018) Marine Natural Products in Medicinal Chemistry. ACS Med Chem Lett 9(10):959-961

36. Mayer AM, Glaser KB, Cuevas C, Jacobs RS, Kem W, Little RD, McIntosh JM, Newman DJ, Potts BC, Shuster DE (2010) The odyssey of marine pharmaceuticals: a current pipeline perspective. Trends Pharmacol Sci 31(6):255-265

37. Mayer AMS, Rodriguez AD, Berlinck RGS, Fusetani N (2011) Marine pharmacology in 2007-8: Marine compounds with antibacterial, anticoagulant, antifungal, anti-inflammatory, antimalarial, antiprotozoal, antituberculosis, and antiviral activities; affecting the immune and nervous system, and other miscellaneous mechanisms of action. Comp Biochem Physiol C Toxicol Pharmacol 153(2):191-222

38. Simmons TL, Andrianasolo E, McPhail K, Flatt P, Gerwick WH (2005) Marine natural products as anticancer drugs. Mol Cancer Ther 4(2):333-342

39. Beutler JA (2009) Natural products as a foundation for drug discovery. Curr Protoc Pharmacol 46:9.11.1-9.11.21

40. Glaser KB, Mayer AM (2009) A renaissance in marine pharmacology: from preclinical curiosity to clinical reality. Biochem Pharmacol 78(5):440-448

41. De Vries DJ, Hall MR (1994) Marine biodiversity as a source of chemical diversity. Drug Develop Res 33(2):161-173

42. Lordan S, Ross RP, Stanton C (2011) Marine bioactives as functional food ingredients: potential to reduce the incidence of chronic diseases. Mar Drugs 9(6):1056-1100

43. Tan LT (2007) Bioactive natural products from marine cyanobacteria for drug discovery. Phytochem 68(7):954-979

44. Newman DJ, Cragg GM (2017) Current status of marine-derived compounds as warheads in anti-tumor drug candidates. Mar Drugs 15(4):99. https://doi.org/10.3390/md15040099

45. Kanase HR, Singh KM (2018) Marine pharmacology: potential, challenges, and future in India. J Med Sci 38:49-53

46. Gerwick WH (2012) Moore BS (2012) Lessons from the past and charting the future of marine natural products drug discovery and chemical biology. Chem Biol 19(1):85-98

47 Price FW (1964) A rapid paper chromatographic technique for simultaneous assay of several enzymes in a tissue homogenate. Anal Biochem 8:24-33

48. Håkanson R (1966) Histidine decarboxylase in experimental tumours. J Pharm Pharmacol 18(12):769-774

49. Grabley S, Thiericke R (1999) Drug discovery from nature. Springer, New York, pp 38-48

50. Cragg GM, Boyd MR, Khanna R, Newman DJ, Sausville EA (1999) Recent advances in phytochemistry. In: Romero JT (ed) Phytochemicals in human health protection, nutrition, and plant defense, vol 33. Kluwer Academic, New York, pp 1-29

51. D'Orazio N, Gammone MA, Gemello E, De Girolamo M, Cusenza S, Riccioni G (2012) Marine bioactives: pharmacological properties and potential applications against inflammatory diseases. Mar Drugs 10(4):812-833
52. Senthilkumar K, Kim SK (2013) Marine invertebrate natural products for anti-inflammatory and chronic diseases. Evid Based Complement Alternat Med 2013:572859

53. Feling RH, Buchanan GO, Mincer TJ, Kauffman CA, Jensen PR, Fenical W (2003) Salinosporamide A: a highly cytotoxic proteasome inhibitor from a novel microbial source, a marine bacterium of the new genus salinospora. Angew Chem Int Ed Engl 42(3):355-357

54. Fenical W, Jensen PR (2006) Developing a new resource for drug discovery: marine actinomycete bacteria. Nat Chem Biol 2(12):666-673

55. Jensen PR, Williams PG, Oh D-C, Zeigler L, Fenical W (2007) Speciesspecific secondary metabolite production in marine actinomycetes of the genus Salinispora. Appl Environ Microbiol 73(4):1146-1152

56. Fenical W, Jensen PR, Palladino MA, Lam KS, Lloyd GK, Potts BC (2009) Discovery and development of the anticancer agent salinosporamide A (NPI-0052). Bioorg Med Chem 17(6):2175-2180

57. Chauhan D, Catley L, Li G, Podar K, Hideshima T, Velankar M, Mitsiades C, Mitsiades N, Yasui H, Letai A, Ovaa H, Berkers C, Nicholson B, Chao T-H, Neuteboom STC, Richardson P, Palladino MA, Anderson KC (2005) A novel orally active proteasome inhibitor induces apoptosis in multiple myeloma cells with mechanisms distinct from Bortezomib. Cancer Cell 8(5):407-419

58. Lam KS, Lloyd GK, Neuteboom STC, Palladino MA, Sethna KM, Spear MA Potts BC (2010). In: Buss AD, Butler MS (eds) Natural product chemistry for drug discovery. Royal Society of Chemistry, Cambridge, p 355

59. Lam KS, Lloyd GK, Neuteboom ST, Palladino MA, Sethna KM, Spear MA, Potts BC (2010) From natural product to clinical trials: NPI-0052 (salinosporamide A), a marine actinomycete derived anticancer agent. Royal Society of Chemistry, Cambridge, pp 355-373

60. Marx LB, Burton JW (2018) A total synthesis of Salinosporamide A Chem Eur J 24:6747

61. Lee HS, Jeong GS (2020) Salinosporamide A, a marine-derived proteasome inhibitor, inhibits $T$ cell activation through regulating proliferation and the cell cycle. Molecules 25(21):5031. https://doi.org/10.3390/ molecules 25215031

62. Gulder TAM, Moore BS (2010) Salinosporamide natural products: Potent $20 S$ proteasome inhibitors as promising cancer chemotherapeutics. Angew Chem Int Ed 49:9346-9367

63. Dou QP, Zonder JA (2014) Overview of proteasome inhibitor-based anti-cancer therapies: perspective on bortezomib and second generation proteasome inhibitors versus future generation inhibitors of ubiquitin-proteasome system. Curr Cancer Drug Targets 14(6):517-536

64. Voorhees PM, Orlowski RZ (2006) The proteasome and proteasome inhibitors in cancer therapy. Annu Rev Pharmacol Toxicol 46:189-213

65. Twombly R (2003) First proteasome inhibitor approved for multiple myeloma. J Natl Cancer Inst 95(12):845

66. Fenteany G, Standaert RF, Lane WS, Choi S, Corey EJ, Schreiber SL (1995) Inhibition of proteasome activities and subunit-specific amino-terminal threonine modification by lactacystin. Science 268(5211):726-731

67. Williams PG (2009) Panning for chemical gold: marine bacteria as a source of new therapeutics. Trends Biotechnol 27(1):45-52

68. Mateos MV, Ocio EM, San Miguel JF (2013) Novel generation of agents with proven clinical activity in multiple myeloma. Semin Oncol 40(5):618-633

69. Wang H, Guan F, Chen D, Dou QP, Yang H (2014) An analysis of the safety profile of proteasome inhibitors for treating various cancers. Expert Opin Drug Saf 13(8):1043-1054

70. Ashjian E, Redic K (2016) Multiple myeloma: updates for pharmacists in the treatment of relapsed and refractory disease. J Oncol Pharm Pract 22(2):289-302. https://doi.org/10.1177/1078155215572036

71. Palombella VJ, Rando OJ, Goldberg AL, Maniatis T (1994) The ubiquitinproteasome pathway is required for processing the NF-kappa B1 precursor protein and the activation of NF-kappa B. Cell 78(5):773-785

72. Chauhan D, Uchiyama H, Akbarali Y, Urashima M, Yamamoto K, Libermann TA, Anderson KC (1996) Multiple myeloma cell adhesion-induced interleukin-6 expression in bone marrow stromal cells involves activation of NF-kappa B. Blood 87(3):1104-1112

73. Russo SM, Tepper JE, Baldwin AS Jr, Liu R, Adams J, Elliott P, Cusack JC Jr (2001) Enhancement of radiosensitivity by proteasome inhibition: implications for a role of NF-kappaB. Int J Radiat Oncol Biol Phys 50(1):183-193 
74. Adams J (2002) Preclinical and clinical evaluation of proteasome inhibitor PS-341 for the treatment of cancer. Curr Opin Chem Biol 6(4):493-500

75. Hideshima T, Chauhan D, Richardson P, Mitsiades C, Mitsiades N, Hayashi T, Munshi N, Dong L, Castro A, Palombella V, Adams J, Anderson KC (2002) NF-kappa B as a therapeutic target in multiple myeloma. J Biol Chem 277(19):16639-16647

76. Ahn KS, Sethi G, Chao TH, Neuteboom ST, Chaturvedi MM, Palladino MA, Younes A, Aggarwal BB (2007) Salinosporamide A (NPI-0052) potentiates apoptosis, suppresses osteoclastogenesis, and inhibits invasion through down-modulation of NF-kappaB regulated gene products. Blood 110(7):2286-2295

77. Fuchs $O$ (2013) Targeting of NF-kappaB signaling pathway, other signaling pathways and epigenetics in therapy of multiple myeloma. Cardiovasc Hematol Disord Drug Targets 13(1):16-34

78. Potts BC, Albitar MX, Anderson KC, Baritaki S, Berkers C, Bonavida B, Chandra J, Chauhan D, Cusack JC Jr, Fenical W, Ghobrial IM, Groll M, Jensen PR, Lam KS, Lloyd GK, McBride W, McConkey DJ, Miller CP, Neuteboom ST, Oki Y, Ovaa H, Pajonk F, Richardson PG, Roccaro AM, Sloss CM, Spear MA, Valashi E, Younes A, Palladino MA (2011) Marizomib, a proteasome inhibitor for all seasons: preclinical profile and a framework for clinical trials. Curr Cancer Drug Targets 11(3):254-284

79. Ma L, Diao A (2015) Marizomib, a potent second generation proteasome inhibitor from natural origin. Anticancer Agents Med Chem 15(3):298-306

80. de la Puente P, Azab AK (2013) Contemporary drug therapies for multiple myeloma. Drugs Today (Barc) 49(9):563-573

81. Williams PG, Buchanan GO, Feling RH, Kauffman CA, Jensen PR, Fenical W (2005) New cytotoxic salinosporamides from the marine actinomycete Salinispora tropica. J Org Chem 70(16):6196-6203

82. Groll M, Ditzel L, Löwe J, Stock D, Bochtler M, Bartunik HD, Huber R (1997) Structure of 20 S proteasome from yeast at 2.4 Aresolution. Nature 386(6624):463-471

83. DeMartino GN, Slaughter CA (1999) The proteasome, a novel protease regulated by multiple mechanisms. J Biol Chem 274(32):22123-22126

84. Goldberg AL, Cascio P, Saric T (2002) Rock KL (2002) The importance of the proteasome and subsequent proteolytic steps in the generation of antigenic peptides. Mol Immunol 39(3-4):147-164

85. Naujokat C (2002) Hoffmann S (2002) Role and function of the 265 proteasome in proliferation and apoptosis. Lab Invest 82(8):965-980

86. Adams J (2004) The proteasome: a suitable antineoplastic target. Nat Rev Cancer 4(5):349-360

87. Williams S, Pettaway C, Song R, Papandreou C, Logothetis C, McConkey DJ (2003) Differential effects of the proteasome inhibitor bortezomib on apoptosis and angiogenesis in human prostate tumor xenografts. Mol Cancer Ther 2:835-843

88. Nawrocki ST, Bruns CJ, Harbison MT, Bold RJ, Gotsch BS, Abbruzzese JL, Elliott P, Adams J, McConkey DJ (2002) Effects of the proteasome inhibitor PS-341 on apoptosis and angiogenesis in orthotopic human pancreatic tumor xenografts. Mol Cancer Ther 1:1243-1253

89. Perez-Galan P, Roue G, Villamor N, Montserrat E, Campo E, Colomer $D$ (2006) The proteasome inhibitor bortezomib induces apoptosis in mantle-cell lymphoma through generation of ROS and Noxa activation independent of p53 status. Blood 107:257-264

90. Fribley A, Zeng Q, Wang CY (2004) Proteasome inhibitor PS-341 induces apoptosis through induction of endoplasmic reticulum stress-reactive oxygen species in head and neck squamous cell carcinoma cells. Mol Cell Biol 24:9695-9704

91. Qin JZ, Ziffra J, Stennett L, Bodner B, Bonish BK, Chaturvedi V, Bennett F, Pollock PM, Trent JM, Hendrix MJ, Rizzo P, Miele L, Nickoloff BJ (2005) Proteasome inhibitors trigger NOXA-mediated apoptosis in melanoma and myeloma cells. Cancer Res 65:6282-6293

92. Scagliotti G (2006) Proteasome inhibitors in lung cancer. Crit Rev Oncol Hematol 58:177-189

93. Adams J (2002) The proteasome as a novel target for the treatment of breast cancer. Breast Dis 15:61-70

94. Yu C, Rahmani M, Dent P, Grant S (2004) The hierarchical relationship between MAPK signaling and ROS generation in human leukemia cells undergoing apoptosis in response to the proteasome inhibitor Bortezomib. Exp Cell Res 295:555-566
95. Yang Y, Kitagaki J, Wang H, Hou DX, Perantoni AO (2009) Targeting the ubiquitin-proteasome system for cancer therapy. Cancer Sci 100(1):24-28

96 Hoeller D, Dikic I (2009) Targeting the ubiquitin system in cancer therapy. Nature 458(7237):438-444

97. Nalepa G, Rolfe M, Harper JW (2006) Drug discovery in the ubiquitinproteasome system. Nat Rev Drug Discov 5(7):596-613

98. Chen ZJ (2005) Ubiquitin signalling in the NF-kappa B pathway. Nat Cell Biol 7(8):758-765

99. Blagosklonny MV (2002) p53: an ubiquitous target of anticancer drugs. Int J Cancer 98(2):161-166

100. Glotzer M, Murray AW, Kirschner MW (1991) Cyclin is degraded by the ubiquitin pathway. Nature 349(6305):132-138

101. Diehl JA, Zindy F, Sherr CJ (1997) Inhibition of cyclin D1 phosphorylation on threonine-286 prevents its rapid degradation via the ubiquintin-proteasome pathway. Genes Dev 11(8):957-972

102. Rajkumar SV, Richardson PG, Hideshima T, Anderson KC (2005) Proteasome inhibition as a novel therapeutic target in human cancer. J Clin Oncol 23:630-639

103. Ling YH, Liebes L, Zou Y, Perez-Soler R (2003) Reactive oxygen species generation and mitochondrial dysfunction in the apoptotic response to Bortezomib, a novel proteasome inhibitor, in human $\mathrm{H} 460$ non-small cell lung cancer cells. J Biol Chem 278:33714-33723

104. Mitsiades N, Mitsiades CS, Poulaki V, Chauhan D, Fanourakis G, Gu X, Bailey C, Joseph M, Libermann TA, Treon SP, Munshi NC, Richardson PG, Hideshima T, Anderson KC (2002) Molecular sequelae of proteasome inhibition in human multiple myeloma cells. Proc Natl Acad Sci USA 99:14374-14379

105. Nawrocki ST, Carew JS, Dunner K Jr, Boise LH, Chiao PJ, Huang P, Abbruzzese JL, McConkey DJ (2005) Bortezomib inhibits PKR-like endoplasmic reticulum (ER) kinase and induces apoptosis via ER stress in human pancreatic cancer cells. Cancer Res 65:11510-11519

106. Miller CP, Ban K, Dujka ME, McConkey DJ, Munsell M, Palladino M, Chandra J (2007) NPI-0052, a novel proteasome inhibitor, induces caspase-8 and ROS-dependent apoptosis alone and in combination with HDAC inhibitors in leukemia cells. Blood 110(1):267-277

107. Chauhan D, Catley L, Li G, Podar K, Hideshima T, Velankar M, Mitsiades C, Mitsiades N, Yasui H, Letai A, Ovaa H, Berkers C, Nicholson B, Chao TH, Neuteboom ST, Richardson P, Palladino MA, Anderson KC (2005) A novelorally active proteasome inhibitor induces apoptosis in multiple myeloma cells with mechanisms distinct from Bortezomib. Cancer Cell 8(5):407-419

108. Sloss CM, Wang F, Palladino MA, Cusack JC Jr (2010) Activation of EGFR by proteasome inhibition requires HB-EGF in pancreatic cancer cells. Oncogene 29(21):3146-3152

109. Baritaki S, Suzuki E, Umezawa K, Spandidos DA, Berenson J, Daniels TR, Penichet ML, Jazirehi AR, Palladino M, Bonavida B (2008) Inhibition of Yin Yang 1-dependent repressor activity of DR5 transcription and expression by the novel proteasome inhibitor NPI-0052 contributes to its TRAIL-enhanced apoptosis in cancer cells. J Immunol 180(9):6199-6210

110. Roccaro AM, Leleu X, Sacco A, Jia X, Melhem M, Moreau AS, Ngo HT, Runnels J, Azab A, Azab F, Burwick N, Farag M, Treon SP, Palladino MA, Hideshima T, Chauhan D, Anderson KC, Ghobrial IM (2008) Dual targeting of the proteasome regulates survival and homing in Waldenstrom macroglobulinemia. Blood 111(9):4752-4763

111. Miller CP, Rudra S, Keating MJ, Wierda WG, Palladino M, Chandra J (2009) Caspase-8 dependent histone acetylation by a novel proteasome inhibitor, NPI-0052: a mechanism for synergy in leukemia cells. Blood 113(18):4289-4299

112. Fenical W (2013) Scripps institution of oceanography, La Jolla, CA, USA. Personal Communication, La Jolla

113. Chauhan D, Singh A, Brahmandam M, Podar K, Hideshima T, Richardson P, Munshi N, Palladino MA, Anderson KC (2008) Combination of proteasome inhibitors bortezomib and NPI-0052 trigger in vivo synergistic cytotoxicity in multiple myeloma. Blood 111(3):1654-1664

114. Richardson PG, Xie W, Jagannath S, Jakubowiak A, Lonial S, Raje NS, Alsina M, Ghobrial IM, Schlossman RL, Munshi NC, Mazumder A, Vesole DH, Kaufman JL, Colson K, McKenney M, Lunde LE, Feather J, Maglio ME, Warren D, Francis D, Hideshima T, Knight R, Esseltine DL, Mitsiades CS, Weller E, Anderson KC (2014) Lenalidomide, Bortezomib, 
and Dexamethasone in patients with relapsed or relapsed/refractory multiple myeloma (MM): encouraging response rates and tolerability with correlation of outcome and adverse cytogenetics in a phase II study. Blood 123(10):1461-1469

115. Kurzrock R, Hamlin P, Younes A, Hong D, Gordon M, Spear MA, Palladino MA, Lloyd GK, Longenecker AM, Neuteboom ST, Cropp GF, Hannah A, Aghajanian C (2007) Phase 1 clinical trial of a novel proteasome inhibitor (NPI-0052) in patients with lymphomas and solid tumors. Blood 110(11):198B

116. Kavallaris M, Verrills NM, Hill BT (2001) Anticancer therapy with novel tubulin-interacting drugs. Drug Resist Updat 4(6):392-401

117. Hadfield JA, Ducki S, Hirst N, McGown AT (2003) Tubulin and microtubules as targets for anticancer drugs. Prog Cell Cycle Res 5:309-325

118. Kingston DG (2009) Tubulin-interactive natural products as anticancer agents. J Nat Prod 72(3):507-515

119. Newman DJ, Cragg GM (2014) Marine-sourced anti-cancer and cancer pain control agents in clinical and late preclinical development. Mar Drugs 12(1):255-278

120. Pettit GR, Kamano Y, Fujii Y, Herald CL, Inoue M, Brown P, Gust D, Kitahara K, Schmidt JM, Doubek DL, Michel C (1981) Marine animal biosynthetic constituents for cancer chemotherapy. J Nat Prod 44(4):482-485

121. Pettit GR, Kamano Y, Dufresne C, Cerny RL, Herald CL, Schmidt JM (1989) Isolation and structure of the cytostatic linear depsipeptide dolastatin 15. J Org Chem 54:6005-6006

122. Pettit GR, Kamano Y, Herald CL, Tuinman AA, Boettner FE, Kizu H, Schmidt JM, Baczynski L, Tomer K, Bontems RJ (1990) The isolation and structure of a remarkable marine animal antineoplastic constituent: dolastatin 10. Biochem Pharmacol 39(12):1941-1949

123. Luesch H, Moore RE, Paul VJ, Mooberry SL, Corbett TH (2001) Isolation of dolastatin 10 from the marine cyanobacterium symploca species VP642 and total stereochemistry and biological evaluation of its analogue symplostatin 1. J Nat Prod 64(7):907-910

124. Williamson RT, Chapin EL, Carr AW, Gilbert JR, Graupner PR, Lewer P, McKamey P, Carney JR, Gerwick WH (2000) New diffusion-edited NMR experiments to expedite the dereplication of known compounds from natural product mixtures. Org Lett 2(3):289-292

125. Flahive E, Srirangam J (2005) Anticancer agents from natural products. In: Cragg GM, Kingston DGl, Newman DJ (eds) Natural products as pharmaceuticals and sources for lead structures. CRC Press, Boca Raton, pp 191-213

126. Banerjee S, Wang Z, Mohammad M, Sarkar FH, Mohammad RM (2008) Efficacy of selected natural products as therapeutic agents against cancer. J Nat Prod 71(3):492-496

127 Singh R, Mukul S, Joshi P, Rawat DS (2008) Clinical status of anti-cancer agents derived from marine sources. Clinical status of anti-cancer agents derived from marine sources. Anticancer Agents Med Chem 8(6):603-617

128. Ray A, Okouneva T, Manna T, Miller HP, Schmid S, Arthaud L, Luduena R, Jordan MA, Wilson $L$ (2007) Mechanism of action of the microtubuletargeted antimitotic depsipeptide tasidotin (formerly ILX651) and its major metabolite tasidotin C-carboxylate. Cancer Res 67(8):3767-3776

129 Bai R, Pettit GR, Hamel E (1990) Dolastatin 10, a powerful cytostatic peptide derived from a marine animal. Inhibition of tubulin polymerization mediated through the Vinca alkaloid binding domain. Biochem Pharmacol 39(12):1941-1949

130. Bai RL, Pettit GR, Hamel E (1990) Binding of dolastatin 10 to tubulin at a distinct site for peptide antimitotic agents near the exchangeable nucleotide and Vinca alkaloid sites. J Biol Chem 265(28):17141-171419

131. Gerwick WH, Tan LT, Sitachitta N (2001) Nitrogen-containing metabolites from marine cyanobacteria. In: Cordell G (ed) The alkaloids. Academic Press, San Diego, pp 75-184

132. Ratnayake R, Gunasekera SP, Ma JJ, Dang LH, Carney TJ, Paul VJ, Luesch H (2020) Dolastatin 15 from a Marine Cyanobacterium Suppresses HIF-1a Mediated Cancer Cell Viability and Vascularization. ChemBioChem 21:2356

133. Mita AC, Hammond LA, Bonate PL, Weiss G, McCreery H, Syed S, Garrison M, Chu QSC, DeBono JS, Jones CB, Weitman S, Rowinsky EK (2006) Phase I and pharmacokinetic study of tasidotin hydrochloride (ILX651), a third-generation dolastatin-15 analogue, administered weekly for 3 weeks every 28 days in patients with advanced solid tumors. Clin Cancer Res 12(17):5207-5215
134. Cunningham C, Appleman $L$, Kirvan-Visovatti M, Ryan DP, Regan E, Vukelja S, Bonate PL, Ruvuna F, Fram RJ, Jekunen A, Weitman S, Hammond LA (2005) Eder JP Jr (2005) Phase I and pharmacokinetic study of the dolastatin-15 analogue tasidotin (ILX651) administered intravenously on days 1,3, and 5 every 3 weeks in patients with advanced solid tumors. Clin Cancer Res 11:7825-7833

135. Gajula PK, Asthana J, Panda D, Chakraborty TK (2013) A synthetic dolastatin 10 analogue suppresses microtubule dynamics, inhibits cell proliferation, and induces apoptotic cell death. J Med Chem 56(6):2235-2245

136. Jordan A, Hadfield JA, Lawernce NJ, McGown AT (1998) Tubulin as a target for anticancer drugs: agents which interact with the mitotic spindle. Med Res Rev 18(4):259-296

137. Bai R, Pettit GR, Hamel E (1992) Dolastatin 10, a powerful cytostatic peptide derived from a marine animal. Inhibition of tubulin polymerization mediated through the Vinca alkaloid binding domain. Biochem Pharmacol 43(12):2637-2645

138. Pettit GR, Srirangam JK, Barkoczy J, Williams MD, Durkin KP, Boyd MR, Bai R, Hamel E, Schmidt JM (1995) Chapuis JC (1995) Antineoplastic agents 337. Synthesis of dolastatin 10 structural modifications. Anticancer Drug Des 10(7):529-544

139. Miyazaki K, Kobayashi M, Natsume T, Gondo M, Mikami T, Sakakibara K (1995) Tsukagoshi S (1995) Synthesis and antitumor activity of novel dolastatin 10 analogs. Chem Pharm Bull (Tokyo) 43(10):1706-1718

140. Harrigan GG, Luesch H, Yoshida WY, Moore RE, Nagle DG, Paul VJ, Mooberry SL, Corbett TH, Valeriote FA (1998) Symplostatin 1:a dolastatin 10 analogue from the marine cyanobacterium Symploca hydnoides. J Nat Prod 61(9):1075-1077

141. Riely GJ, Gadgeel S, Rothman I, Saidman B, Sabbath K, Feit K, Kris MG, Rizvi NA (2007) A phase 2 study of TZT-1027, administered weekly to patients with advanced non-small cell lung cancer following treatment with platinumbased chemotherapy. Lung Cancer 55(2):181-185

142. Otani M, Natsume T, Watanabe Jl, Kobayashi M, Murakoshi M, Mikami T, Nakayama T (2000) TZT-1027, an antimicrotubule agent, attacks tumor vasculature and induces tumor cell death. Jpn J Cancer Res 91(8):837-844

143. Kobayashi M, Natsume T, Tamaoki S et al (1997) Antitumor activity of TZT-1027, a novel dolastatin 10 derivative. Jpn J Cancer Res 88(3):316-327

144. Butler MS (2008) (2008) Natural products to drugs: natural productderived compounds in clinical trials. Nat Prod Rep 25(3):475-516

145. Cruz-Monserrate Z, Mullaney J, Harran P, Pettit GR, Hamel E (2003) Dolastatin 15 binds in the Vinca domain of tubulin as demonstrated by hummel-dreyer chromatography. Eur J Biochem 270(18):3822-3828

146. de Arruda M, Cocchiaro CA, Nelson CM, Grinnell C, Janssen B, Haupt A, Barlozzari T (1995) LU103793 (NSC D-669356): a synthetic peptide that interacts with microtubules and inhibits mitosis. Cancer Res 55(14):3085-3092

147. Newman DJ, Cragg GM (2004) Marine natural products and related compounds in clinical and advanced preclinical trials. J Nat Prod 67(8):1216-1238

148. Ebbinghaus S, Hersh E, Cunningham CC, et al. Phase II study of synthadotin (SYN-D; ILX651) administered daily for 5 consecutive days once every 3 weeks in patients with inoperable locally advanced or metastatic melanoma. In: Proceedings of the 2004 American society of clinical oncology annual meeting; Abstr \#7530. In 2004.

149. Jordi R, Jordana MB, Daniel PZ, Marc NJ, Roger P, Lourdes M, Carles $Q$, Carles P, Itziar E, Ignacio B, Alfonso V, Víctor G, Jorge C, Julià B, Joaquim S, Bonaventura C, Júlia VA, Nuria IU (2021) Identification of plitidepsin as potent inhibitor of SARS-CoV-2-induced cytopathic effect after a drug repurposing screen. Front Pharmacol 12:278

150. Ocio EM, Mateos MV, Maiso P, Pandiella A, San-Miguel JF (2008) New drugs in multiple myeloma: mechanisms of action and phase I/II clinical findings. Lancet Oncol 9(12):1157-1165

151. Muñoz-Alonso MJ, González-Santiago L, Martínez T, Losada A, Galmarini CM, Muñoz A (2009) The mechanism of action of plitidepsin. Curr Opin Investig Drugs 10(6):536-542

152. Nalda-Molina R, Valenzuela B, Ramon-Lopez A, Miguel-Lillo B, SotoMatos A, Perez-Ruixo JJ (2009) Population pharmacokinetics metaanalysis of plitidepsin (Aplidin) in cancer subjects. Cancer Chemother Pharmacol 64(1):97-108 
153. Ribrag V, Caballero D, Fermé C, Zucca E, Arranz R, Briones J, Gisselbrecht C, Salles G, Gianni AM, Gomez H, Kahatt C, Corrado C, Szyldergemajn S, Extremera S, de Miguel B, Cullell-Young M, Cavalli F (2013) Multicenter phase II study of plitidepsin in patients with relapsed/refractory nonHodgkin's lymphoma. Haematologica 98(3):357-363

154 Martinez MA (2021) Plitidepsin: a repurposed drug for the treatment of COVID-19. Antimicrob Agents Chemother 65(4):e00200-21. https://doi. org/10.1128/AAC.00200-21

155. Le Tourneau C, Raymond E, Faivre S (2007) Aplidine: a paradigm of how handling activity and toxicity of novel marine anticancer poison. Curr Pharm Des 13(33):3427-3439

156. Le Tourneau C, Faivre S, Ciruelos E, Domínguez MJ, López-Martín JA, Izquierdo MA, Jimeno J, Raymond E (2010) Reports of clinical benefit of plitidepsin (Aplidine), a new marine-derived anticancer agent, in patients with advanced medullary thyroid carcinoma. Am J Clin Oncol 33(2):132-136

157. García-Fernández LF, Losada A, Alcaide V, Alvarez AM, Cuadrado A, González L, Nakayama K, Nakayama Kl, Fernández-Sousa JM, Muñoz A, Sánchez-Puelles JM (2002) Aplidin induces the mitochondrial apoptotic pathway via oxidative stress-mediated JNK and p38 activation and protein kinase C delta. Oncogene 21(49):7533-7544

158. Suarez Y, Gonzalez-Santiago L, Zarich N, Davalos A, Aranda JF, Alonso MA, Lasuncion MA, Rojas JM, Munoz A (2006) Plitidepsin cellular binding and Rac1/JNK pathway activation depend on membrane cholesterol content. Mol Pharmacol 70(5):1654-1663

159. Gonzalez-Santiago L, Suarez Y, Zarich N, Munoz-Alonso MJ, Cuadrado A, Martinez T, Goya L, Iradi A, Saez-Tormo G, Maier JV (2006) Aplidin induces JNK-dependent apoptosis in human breast cancer cells via alteration of glutathione homeostasis, Rac1 GTPase activation, and MKP-1 phosphatase downregulation. Cell Death Differ 13(11):1968-1981

160. Urdiales JL, Morata P, de Castro IN, Sánchez-Jiménez F (1996) Antiproliferative effect of dehydrodidemnin $B(D D B)$, a depsipeptide isolated from Mediterranean tunicates. Cancer Lett 102(1-2):31-37

161. Depenbrock H, Peter R, Faircloth GT, Manzanares I, Jimeno J, Hanauske AR (1998) In vitro activity of aplidine, a new marine-derived anti-cancer compound, on freshly explanted clonogenic human tumour cells and haematopoietic precursor cells. Br J Cancer 78(6):739-744

162. Gajate C, Mollinedo F (2001) The antitumor ether lipid ET-18-OCH(3) induces apoptosis through translocation and capping of Fas/CD95 into membrane rafts in human leukemic cells. Blood 98(13):3860-3863

163. Gajate C, Mollinedo F (2005) Cytoskeleton-mediated death receptor and ligand concentration in lipid rafts forms apoptosis-promoting clusters in cancer chemotherapy. J Biol Chem 280(12):11641-11647

164. Gajate C, Mollinedo F (2007) Edelfosine and perifosine induce selective apoptosis in multiple myeloma by recruitment of death receptors and downstream signaling molecules into lipid rafts. Blood 109(2):711-719
165. Mitsiades CS, Ocio EM, Pandiella A, Maiso P, Gajate C, Garayoa M, Vilanova D, Montero JC, Mitsiades N, McMullan CJ, Munshi NC, Hideshima T, Chauhan D, Aviles P, Otero G, Faircloth G, Mateos MV, Richardson PG, Mollinedo F, San-Miguel JF, Anderson KC (2008) Aplidin, a marine organism-derived compound with potent antimyeloma activity in vitro and in vivo. Cancer Res 68(13):5216-5225

166. Morande PE, Zanetti SR, Borge M, Nannini P, Jancic C, Bezares RF, Bitsmans A, Gonzalez M, Rodriguez AL, Galmarini CM (2012) The cytotoxic activity of Aplidin in chronic lymphocytic leukemia (CLL) is mediated by a direct effect on leukemic cells and an indirect effect on monocytederived cells. Invest New Drugs 30(5):1830-1840

167. Medina RA, Goeger DE, Hills P, Mooberry SL, Huang N, Romero LI (2008) McPhail KL (2008) Coibamide A, a potent antiproliferative cyclic depsipeptide from the Panamanian marine cyanobacterium Leptolyngbya sp. J Am Chem Soc 130(20):6324-6325

168. Costa M, Costa-Rodrigues J, Fernandes MH, Barros P, Vasconcelos V, Martins R (2012) Marine cyanobacteria compounds with anticancer properties: a review on the implication of apoptosis. Mar Drugs 10(10):2181-2207

169. Tranter D, Platero AO, Kawaguchi S, Kazemi S, Serrill JD, Kellosalo J Vogel WK, Richter U, Mattos DR, Wan X, Thornburg CC, Oishi S, McPhail KL, Ishmael JE, Paavilainen VO (2020) Coibamide A targets sec 61 to prevent biogenesis of secretory and membrane proteins. ACS Chem Biol 15(8):2125-2136

170. Hau AM, Greenwood JA, Löhr CV, Serrill JD, Proteau PJ, Ganley IG, Ishmael JE (2013) Coibamide A induces mTOR-independent autophagy and cell death in human glioblastoma cells. PLoS ONE 8:e65250

171. Brennan C (2011) Genomic profiles of glioma. Curr Neurol Neurosci Rep 11:291-297

172. Lin X, Liu M, Hu C, Liao DJ (2010) Targeting cellular proapoptotic molecules for developing anticancer agents from marine sources. Curr Drug Targets 11:708-715

173. Blayney DW, Zhang Q, Feng J, Zhao Y, Bondarenko I, Vynnychenko I, Kovalenko N, Nair S, Ibrahim E, Udovista DP, Mohanlal R, Ogenstad S, Ette E, Du L, Huang L, Shi YK (2020) Efficacy of Plinabulin vs Pegfilgrastim for prevention of chemotherapy-induced neutropenia in adults with non-small cell lung cancer: a phase 2 randomized clinical trial. JAMA Oncol 6(11):e204429. https://doi.org/10.1001/jamaoncol.2020. 4429

\section{Publisher's Note}

Springer Nature remains neutral with regard to jurisdictional claims in published maps and institutional affiliations.

\section{Submit your manuscript to a SpringerOpen ${ }^{\odot}$ journal and benefit from:}

- Convenient online submission

- Rigorous peer review

- Open access: articles freely available online

- High visibility within the field

- Retaining the copyright to your article

Submit your next manuscript at $\boldsymbol{\nabla}$ springeropen.com 